\title{
NEOTECTONIC-RELATED LANDFORMS IN THE CAMPOS DO JORDÃO PLATEAU, SOUTHEAST BRAZIL
}

Silvio Takashi HIRUMA

Claudio RICCOMINI

May Christine MODENESI-GAUTTIERI

\begin{abstract}
The Campos do Jordão Plateau, situated in the Serra da Mantiqueira western flank of the Continental Rift of Southeastern Brazil, presents several morphological features that are indicative of neotectonic activity. This paper presents a morphotectonic map of the southeastern front of the plateau (scale $1: 25,000$ ), based on detailed photointerpretation, with structural data obtained during field surveys and also supported by morphometric analysis. The map illustrates morphotectonic features (triangular and trapezoidal facets, rectilinear escarpments, low drainage divides, shutter ridges and drainage captures) and their relationship with brittle structures and lithotypes. Triangular and trapezoidal facets and rectilinear escarpments are commonly associated with normal faults, whereas low divides and shutter ridges are associated with strike-slip ones. The map provides insights into the neotectonic activity and its influence on the landforms in southeast Brazil.
\end{abstract}

Keywords: Neotectonics; Morphotectonics; Campos do Jordão Plateau; Serra da Mantiqueira.

\section{RESUMO}

FORMAS DE RELEVO ASSOCIADAS A NEOTECTÔNICA NO PLANALTO DE CAMPOS DO JORDÃO, SUDESTE DO BRASIL. O Planalto de Campos do Jordão, situado na Serra da Mantiqueira, flanco oeste do Rift Continental do Sudeste do Brasil, apresenta diversas feições morfológicas indicativas de atividade neotectônica. $\mathrm{O}$ artigo apresenta o mapa morfotectônico do frontão sudeste do planalto (escala 1:25.000), baseado em fotointerpretação de detalhe e dados estruturais obtidos em levantamentos de campo, com o auxílio da análise morfométrica. O mapa documenta feições morfotectônicas (facetas triangulares e trapezoidais, escarpas retilíneas, divisores rebaixados, shutter ridges, capturas de drenagem) e suas relações com as estruturas rúpteis e litotipos. Facetas triangulares e trapezoidais e escarpas retilíneas estão comumente associadas a falhas com componente normal, enquanto divisores rebaixados e shutter ridges estão relacionados a falhas transcorrentes. O mapa fornece subsídios para o entendimento da atividade neotectônica e sua influência nas formas de relevo no sudeste do Brasil.

Palavras-chaves: Neotectônica; Morfotectônica; Planalto de Campos do Jordão; Serra da Mantiqueira. 


\section{INTRODUCTION}

Southeast Brazil is a classic example of a passive continental margin with Great Escarpments (OLLIER 1985, THOMAS 1994). Despite the intraplate setting of Brazil, recent structural, geomorphological and seismological data confirm the importance of neotectonic activity (RICCOMINI \& ASSUMPÇÃO 1999) in different areas of the country.

Neotectonics is frequently associated with morphotectonics, which deals with landforms related to recent tectonism (DOORNKAMP 1986). The effects of neotectonic activity on landforms have been described in different areas of Southeast Brazil (RICCOMINI 1989, RICCOMINI et al. 1989, SAADI 1991, MELO et al. 1993, CAMPANHA et al. 1994, MELLO et al. 1999, GONTIJO 1999, HIRUMA et al. 2001, MODENESI-GAUTTIERI et al. 2002, NEVES et al. 2003, GROHMANN et al. 2007, MENDES et al. 2007, GUEDES et al. 2009, HARTWIG \& RICCOMINI 2010, GONTIJO-PASCUTTI et al. 2010, SILVA \& MELLO 2011, MARQUES NETO \& PEREZ FILHO 2013, PINHEIRO \& QUEIROZ NETO 2015, among others).

The Continental Rift of Southeastern Brazil (RICCOMINI 1989, RICCOMINI et al. 2004) - a Paleogene tectonic depression that extends from Curitiba (Paraná) to Barra de São João (Rio de Janeiro) - is one of the most studied areas in Brazil with respect to Neotectonics. The Campos do Jordão Plateau (Figure 1), situated at the Serra da Mantiqueira, on the western flank of the Continental Rift of Southeastern Brazil, presents evidence of landforms associated with Neotectonics.

RUELLAN (1952) and SAADI (1991) reported the subdivision of this plateau into faulted and tilted blocks. MODENESI (1980, 1983, 1988a, 1988b) identified drainage anomalies along the Jundiuvira shear zone and triangular/trapezoidal facets in the Morro da Pedra do Fogo and Ribeirão do Fojo Valley in the Campos do Jordão Plateau. A more detailed analysis of the southeastern front of the plateau was carried out by HIRUMA (1999), HIRUMA et al. (2001) and MODENESIGAUTTIERI et al. (2002) and reinforced the neotectonic influence in the geomorphic compartmentalization of the plateau.

A morphotectonic map of the southeastern front of the Campos do Jordão Plateau, scale 1:25,000, here presented, was made based on detailed photointerpretation, structural data obtained from field surveys and morphometric analysis. The map compiled information obtained from previous studies in the Campos do Jordão Plateau (HIRUMA 1999, HIRUMA et al. 2001, MODENESI-GAUTTIERI et al. 2002).

\section{THE CAMPOS DO JORDÃO PLATEAU}

The Campos do Jordão Plateau (Figures 1, 2) is an uplifted crystalline block mountain reaching more than 2,000 $\mathrm{m}$, located at the southeastern edge of the Serra da Mantiqueira - western flank of the central segment of the Continental Rift of Southeastern Brazil (RICCOMINI 1989, RICCOMINI et al. 2004). The plateau is bounded by two NE-trending shear zones of Precambrian and Early Paleozoic ages: the Jundiuvira Fault (HASUI et al. 1978) at the SE border, near the Serra da Mantiqueira scarp, and the Paiol Grande Fault (HASUI et al. 1978) - NW border, also known as São Bento do Sapucaí Fault (CAVALCANTE et al. 1979) on its northern flank (Figure 2).

The plateau, with altitudes above $2,000 \mathrm{~m}$, is one of the summit areas of Southeast Brazil (Figure 1), where remnants of the oldest planation surfaces have been preserved (DE MARTONNE 1943, ALMEIDA 1964, AB'SÁBER 2000).

The Campos do Jordão Plateau is inserted into the central sector of the Mantiqueira Structural Province (ALMEIDA \& HASUI 1984), including terrains associated with the Socorro-Guaxupé Orogen (PERROTA et al. 2005). These terrains were amalgamated during the Neoproterozoic (ca. 630-610 Ma), resulting in the consolidation of Western Gondwana (BRITO NEVES et al. 1999, CAMPOS NETO 2000). During the Late Jurassic and Early Cretaceous, tectonic reactivation processes led to the breakup of Western Gondwana and the opening of the Atlantic Ocean between South America and Africa. During the Paleogene, extensional processes gave origin to the Continental Rift of Southeastern Brazil (RICCOMINI 1989, RICCOMINI et al. 2004) - a tectonic depression parallel to the coastline, filled by Cenozoic deposits. The Campos do Jordão Plateau is part of the central segment of the rift, which is morphologically expressed by the Paraíba do Sul River Valley and the mountain ranges of the Serra do Mar and the Serra da Mantiqueira, its eastern and western flanks, respectively. 




FIGURE 1 - (A) Digital elevation model shows the location of the Campos do Jordão Plateau (white line) and the study area (red line) in the central segment of the Continental Rift of Southeastern Brazil. Summit areas: 1 - Campos do Jordão Plateau, 2 - Passa Quatro Alkaline Massif, 3 - Itatiaia Alkaline Massif, 4 - Monte Verde Plateau, 5 - Bocaina Plateau. (B) Geological setting of the Continental Rift of Southeatern Brazil. Main cenozoic deposits of the eastern segment: 1 - Itaboraí Basin, 2- Barra de São João Graben, 3 - Macacu Basin. Central segment: 4 - Volta Redonda Basin, 5 - Resende Basin, 6 - Taubaté Basin, 7 - São Paulo Basin; Western segment: 8 - Sete Barras Graben, 9 - Pariquera-Açu Formation, 10 - Alexandra Formation and Guaraqueçaba Graben, 11 Curitiba Basin, 12 - Cananéia Graben (Modified from MELO et al. 1985, RICCOMINI et al. 2004, CPRM 2006).

The tectonic model proposed for the central segment of the rift based on structuralstratigraphic relationships is characterized by the superposition of stress tectonic regimes (RICCOMINI 1989): (1) an initial Paleogene NNW-SSE extension associated with the original depression, (2) NW-SE extension and local NESW compression (Miocene) associated with structural highs that caused the segmentation of the original rift depression, (3) NW-SE Late Pleistocene-Holocene compressive stress regime, compatible with an E-W right-lateral 

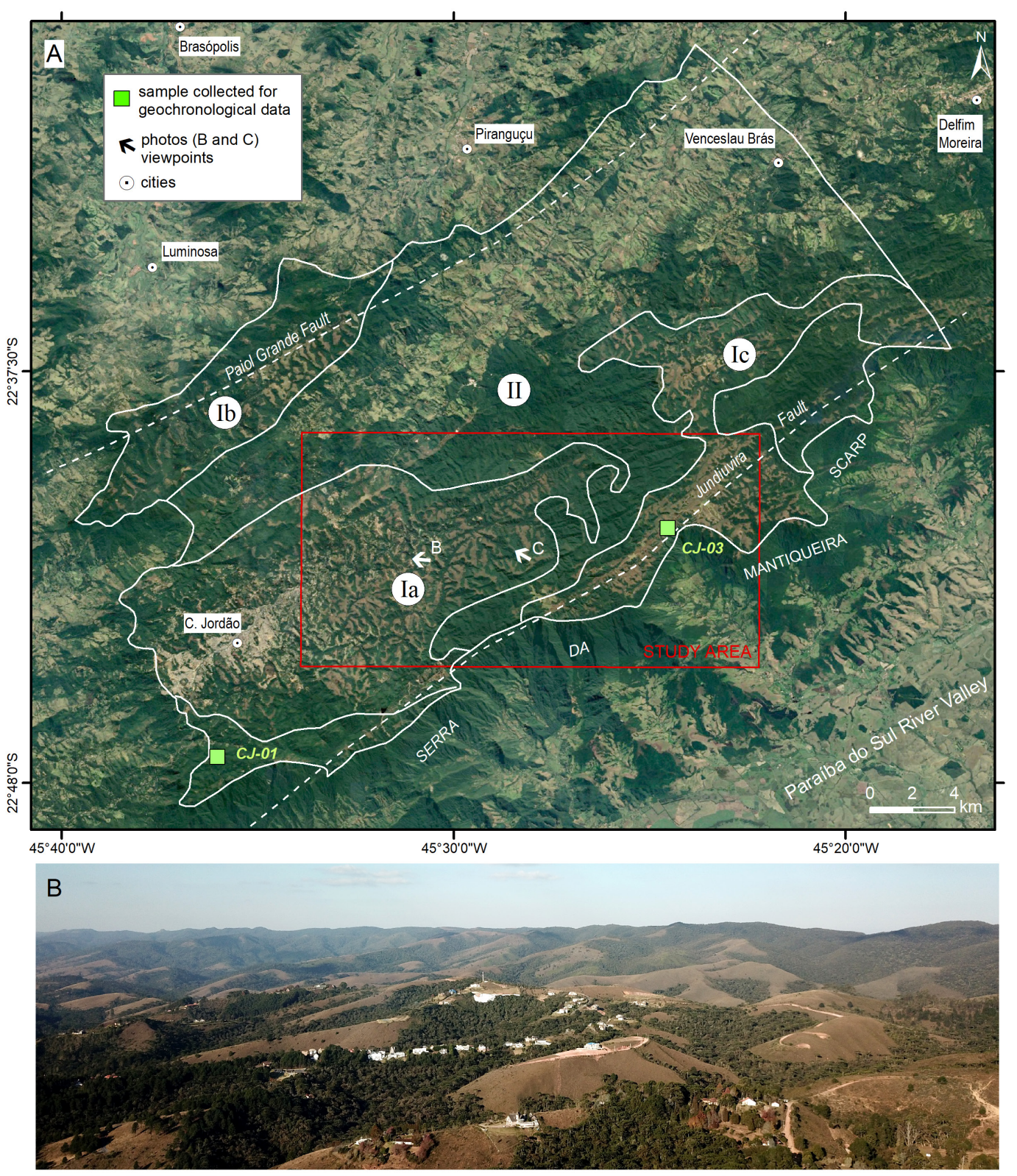

C

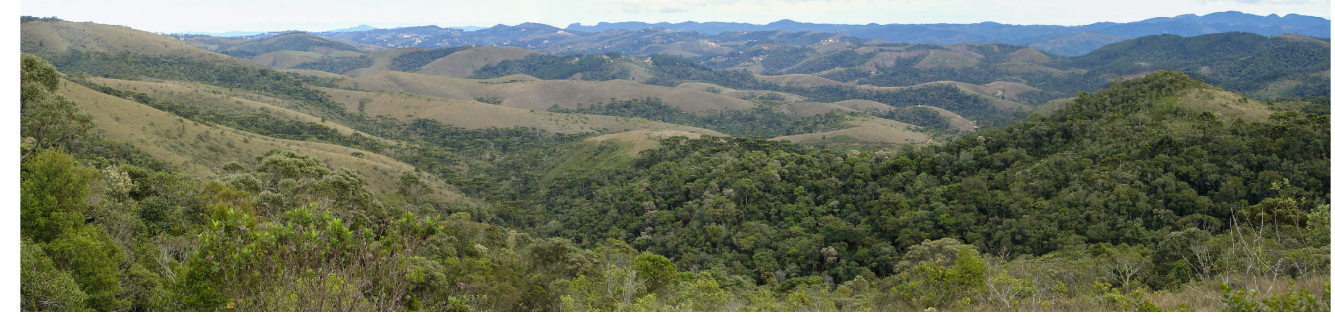

FIGURE 2 - (A) Geosystem units of the Campos do Jordão Plateau: altos campos geosystem: Ia - campos do Jordão, Ib - campos do Serrano, Ic - campos do São Francisco, II - Serrano geosystem (Modified from MODENESI 1988a). Location of the thermochronological data (CJ-01 and CJ-03 samples in green squares). Google Earth image. (B) and (C): the altos campos mosaic of vegetation. See photo views (arrows) (B) and (C) in the image (A). Drone photo (B) by José A. Ferrari. 
strike-slip binary, (4) E-W to NW-SE Holocene extension, (5) E-W compression, compatible with the present-day horizontal maximum stress obtained from geophysical data. This model has been also recognized in the eastern segment of the rift (FERRARI 2001), Precambrian crystalline areas near the Cenozoic basins (FERNANDES DA SILVA 1998, HIRUMA et al. 2001, MODENESI-GAUTTIERI et al. 2002, HARTWIG \& RICCOMINI 2009), Doce River Middle Valley (MELLO et al. 1999), and at the border of the Paraná basin (FERNANDES \& AMARAL 2002).

Successive episodes of uplift and denudation events have affected the region since the breakup of Western Gondwana, recorded by thermochronological data (GALLAGHER et al. 1994, TELLO SAENZ et al. 2003, HACKSPACHER et al. 2004, HIRUMA et al. 2010, COGNÉ et al. 2012). The uplifts associated with the evolution of the Continental Rift of Southeastern Brazil affected the weathering evolution of the plateau (MODENESIGAUTTIERI et al. 2011) and generated a landscape system adapted to the high altitude conditions in the Quaternary - the altos campos (high grasslands) geosystem, clearly identified by a grassland - forest mosaic (MODENESI 1988a). Grasslands occupy the hilltops and convexized slopes with shallow and highly weathered materials, whereas forest cover the rectilinear slopes and erosion amphitheaters with less weathered and deeper materials occur (Figure 2 A-C).

Differences in the degree of relief dissection, depth of weathering and lithology generated small variations in the altos campos physiognomy (MODENESI 1988a): campos do Jordão proper, campos de São Francisco, and campos do Serrano (Figure 2A). At lower topographic positions the Serrano geosystem occurs in the deeply dissected areas of the subsequent drainage (Ribeirão dos Marmelos, Ribeirão do Jacu and Ribeirão do Coxim).

\section{METHODS}

The morphotectonic map of the southeastern front of the plateau (scale 1:25,000) was developed based on detailed photointerpretation, field work and morphometric analysis, following the morphotectonic approach presented by DOORNKAMP (1986) and PANIZZA \& CASTALDINI (1987).

The term Neotectonics was introduced by OBRUCHEV (1948) to refer to "recent tectonic movements that occurred in the upper part of Tertiary (Neogene) and in the Quaternary, which played an essential role in the origin of the contemporaneous topography". The INQUA Neotectonic Commission (MÖRNER 1989) defined this term as any Earth movement or deformation of the geodetic reference level, their mechanisms, their origins and practical applications, and their future extrapolations.

Morphotectonics is used here to denote landforms or landscapes originated by active tectonic control (SAADI 1991). One of the main problems in morphotectonic analysis, according to VERSTAPPEN (1983), consists of distinguishing old movements (and associated forms) from younger events and/or forms. One of the criteria for the identification of true neotectonic features would be the recognition of the age of the most recent layers affected by these movements; the other would be the degree of youth of the created forms (abrupt and undissected scarps, well-preserved facets, linear base of the scarps, among others).

GOY et al. (1991) proposed a model for a morphoneotectonic map and legend that consists of the cartographic representation of geomorphological indicators of active and recent tectonics. They subdivide the geomorphological anomalies into five thematic groups, related to: (1) fault scarps and lines, (2) deformed surficial deposits, (3) interfluves and slopes, (4) drainage network, and (5) geometric-spatial disposition of surficial deposits. The legend of the morphotectonic map presented here, was based and adapted from PANIZZA \& CASTALDINI (1987) and GOY et al. (1991), including geological, geomorphological and geochronological data.

Detailed photointerpretation on a scale of 1:25,000 (aerial photographs by Secretaria da Agricultura, 1972) allowed the recognition of areas with Quaternary deposits (alluvial plains) and the identification of morphological features indicative of recent tectonism, such as rectilinear scarps (WALLACE 1978, STEWART \& HANCOCK 1990), triangular and trapezoidal facets (WALLACE 1978), drainage captures (BIANCOTTI 1979), shutter ridges (COTTON 1948), hanging valleys (MODENESI 1988a), river captures (BIANCOTTI 1979), lakes (COTTON 1948), among others. The figure 3 illustrates the morphotectonic analysis based on the interpretation of vertical aerial photographs.

The topographic base map (scale 1:25,000) was compiled from $1: 10,000$ topographic 


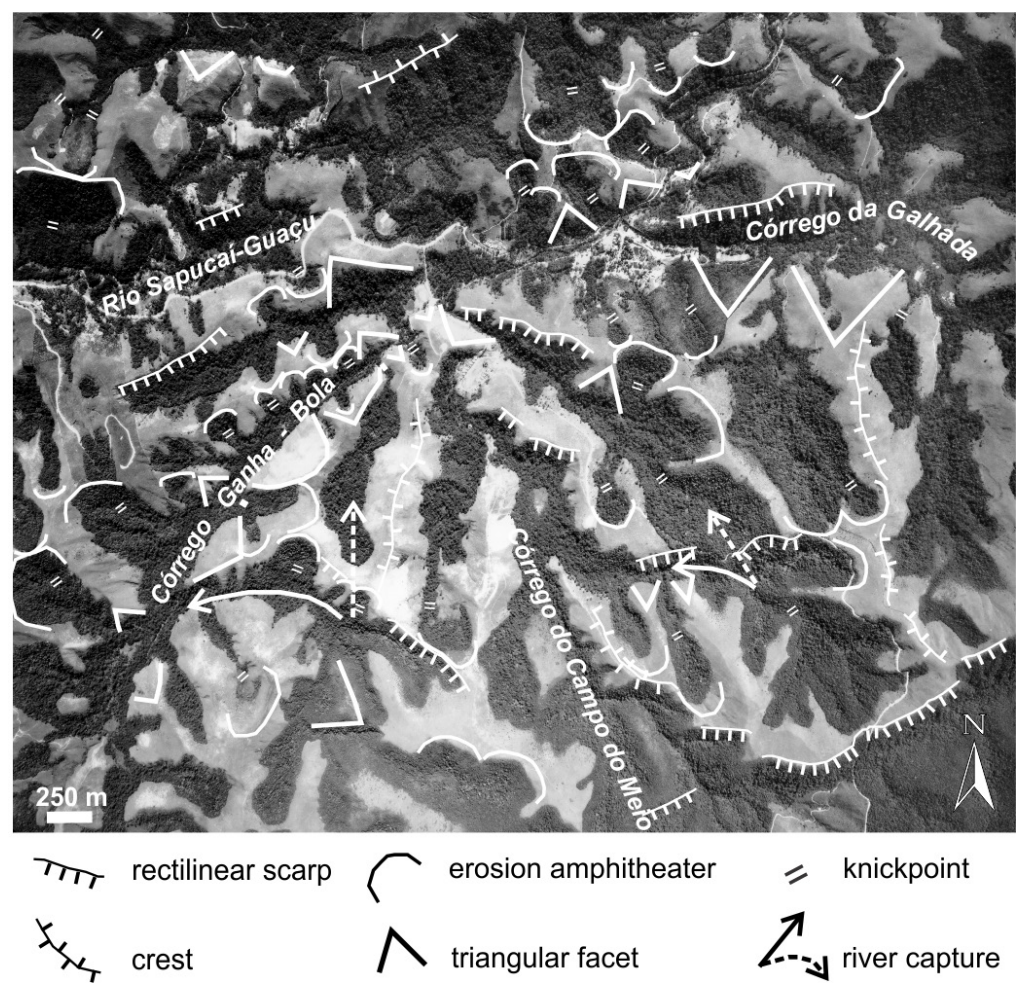

FIGURE 3 - Morphotectonic analysis based on the photointerpretation (1:25.000, vertical aerial photograph, Secretaria da Agricultura, 1972). See location of the figure in the map (Appendix 1).

maps produced by the Instituto Geográfico e Cartográfico IGC (1977), including the following elements: contour lines, altimetric elevations (spot heights), hydrography and roads.

Morphometric maps (hypsometry, slope and aspect terrain) were produced in order to support the morphotectonic analysis. These maps were derived from the 1 Arc-Second Digital Elevation Model from Shuttle Radar Topography Mission (SRTM/NASA).

Morphostructural lineaments were manually extracted based on LANDSAT satellite images $(1: 100,000$ and $1: 250,000)$, radar imagery $(1: 250,000)$ and also a set of shaded relief maps derived from a Digital Elevation Model with different lighting directions (LIU 1987, RICCOMINI \& CRÓSTA 1988). The main trends of the lineaments were established based on rose diagrams.

The integrated analysis of morphometry, morphostructural lineaments and photo-interpreted morphotectonic features allowed the selection of areas with a higher probability for the occurrence of tectonic structures in the field studies.
The geological map was compiled from previous studies (HASUI et al. 1978, CAVALCANTE et al. 1979, MORAIS et al. 1999) and complemented by field studies. Brittle structures were collected and analyzed by graphic methods (ANGELIER \& MECHLER 1977, ANGELIER 1994). The sense of movement of the faults was inferred by kinematic indicators (PETIT 1987, ANGELIER 1994, DOBLAS et al. 1997).

Low-temperature thermochronological data from two samples collected at the southeastern border of the Campos do Jordão Plateau (CJ-01 - Pico do Diamante - 1,785 m, CJ-03 - São José dos Alpes $1,939 \mathrm{~m}$, see location in figure 2) provided information about the regional denudation processes. This method is an important tool to constrain the thermal history of the rocks of the upper portion of the crust on timescales from millions to hundreds of millions years ago. Apatite fission track analysis was carried out at the Instituto de Geociências e Ciências Exatas, UNESP, Rio Claro, SP, Brazil. In addition, ${ }^{238} \mathrm{U} /{ }^{206} \mathrm{~Pb}$ and ${ }^{235} \mathrm{U} / 207 \mathrm{~Pb}$ analyses for sample CJ-03 were performed by ChronusCamp Research-Thermochronology Analysis LTD, Itapira, SP, Brazil. 


\section{NEOTECTONIC-RELATED LANDFORMS}

The morphotectonic map (Appendix 1 Morphotectonic map of the southeastern front of the Campos do Jordão Plateau, SP) shows the distribution of morphotectonic features, brittle structures and lithotypes in the studied area.

Gneisses, granites, schists, quartzites, migmatites correspond to the main lithotypes of the area. Metasediments of the Pico de Itapeva Formation occurs in a small Ediacaran basin at the SE edge of the plateau (TEIXEIRA et al. 2004). Metamorphic foliation strikes trending ENE to $\mathrm{NE}$ and dips in general steeply to the NW or SE.

The apatite fission track ages of the samples CJ-01 (112 $\pm 12 \mathrm{Ma})$ and CJ-03 (92 $\pm 10 \mathrm{Ma})-$ collected at the southeastern border of the plateau - provide information about the thermo-tectonic evolution of the plateau (Table 1, Figure 2, Appendix 1).

Both are much younger than their host rocks, showing that the samples have been exposed to elevated temperatures $\left(>110{ }^{\circ} \mathrm{C}\right)$ after their formation. The ages of ${ }^{238} \mathrm{U} /{ }^{206} \mathrm{~Pb}(642.4 \pm 12.4$ $\mathrm{Ma})$ and ${ }^{235} \mathrm{U} / 207 \mathrm{~Pb}(663.2 \pm 16.7 \mathrm{Ma})$ obtained for sample CJ-03 are probably associated with the assembly of Western Gondwana. Mean track lengths and standard deviations of the samples are coherent with a slow cooling history and a prolonged residence time within the partial annealing zone. The thermal history of sample CJ-03 shows a continuous cooling (80 - $30 \mathrm{Ma})$, probably linked to uplift and denudation processes associated with the Late Cretaceous alkaline magmatism and the evolution of the Continental Rift of Southeastern Brazil.

The main trends of morphostructural lineaments are: (1) NE-SW/ENE-WSW, which corresponds to the regional Precambrian basement fabric (Jundiuvira, Paiol Grande and Buquira shear zones and metamorphic foliation of the rocks) reactivated as brittle faults during the Cenozoic, and (2) N-S/NW-SE, which reflects more recent brittle structures. Precambrian shear zones act as permanent crustal weakness zones with a higher probability of tectonic reactivation, which is demonstrated by the greatest concentration of morphotectonic features along the Jundiuvira shear zone at the southeast border of the Campos do Jordão Plateau.

The following situations involving Quaternary deposits, morphotectonic features and brittle structures could be observed in field surveys: (a) brittle structures affecting Quaternary deposits, with clear association with morphotectonic features; (b) brittle structures affecting Precambrian rocks, with clear association with morphotectonic features; in these cases, the preservation of these features is indicative of the recentness of the tectonic deformation; (c) faults affecting Precambrian rocks, without clear association with morphotectonic features; in these cases tectonic events could be older.

The southeast border of the Campos do Jordão Plateau is delimited by a steep escarpment (slopes $>30^{\circ}$, Appendix 1) up to $1,200 \mathrm{~m}$ high that separates the top of the plateau from the Paraíba do Sul River Valley (Figure 4A-C). The trace of the scarp is conditioned by the intersection of NESW and NW-SE morphostructural lineaments, and coincides in large part with the Jundiuvira Shear Zone. This Precambrian weakness zone was tectonically reactivated during the Paleogene NNW-SSE extension as a normal fault, and later in the Quaternary.

The highest part $(1,900-2,007 \mathrm{~m})$ of the studied area - Serra da Mantiqueira divide - is characterized by low relief (Figure 4D, Appendix 1), corresponding to the campos de São Francisco geosystem. Knickpoints along morphostructural lineaments separates this low relief area from the

TABLE 1 - Results of fission track thermochronology analysis from the Campos do Jordão Plateau. Analyses followed the recommended format of HURFORD (1990) for zeta external detector method. $\rho s / \rho i=$ fossil track density in apatite/ induced track density counted in external (muscovite) detector; $\mathrm{Ns}=$ total number of fossil tracks in apatite; $\mathrm{Ni}=$ total number of induced tracks in muscovite; $\mathrm{L}=$ mean track length $(\mu \mathrm{m})$.

\begin{tabular}{|c|c|c|c|c|c|c|c|c|c|}
\hline Sample & $\begin{array}{l}\text { Altitude } \\
\text { (m) }\end{array}$ & $\begin{array}{l}\text { Number of } \\
\text { crystals }\end{array}$ & $\rho s / \rho i$ & $N s$ & $N i$ & $\begin{array}{c}L(\mu m) / \\
n^{o} L\end{array}$ & $\begin{array}{c}\text { Standard } \\
\text { deviation - L }\end{array}$ & $R_{u}$ & $\begin{array}{c}\text { Zeta age } \\
\text { (Ma) }\end{array}$ \\
\hline CJ-01 & 1,785 & 90 & 1.336 & 1537 & 1322 & $\begin{array}{l}12.42 \\
/ 14\end{array}$ & 1,37 & $\begin{array}{c}(1.0523 \\
\pm 0.0343) 10-8\end{array}$ & $112 \pm 12$ \\
\hline CJ-03 & 1,939 & 111 & 1.089 & 2090 & 1961 & $\begin{array}{l}12.42 \\
/ 58\end{array}$ & 1,49 & $\begin{array}{c}(1.0523 \\
\pm 0.0343) 10^{-8}\end{array}$ & $92 \pm 10$ \\
\hline
\end{tabular}



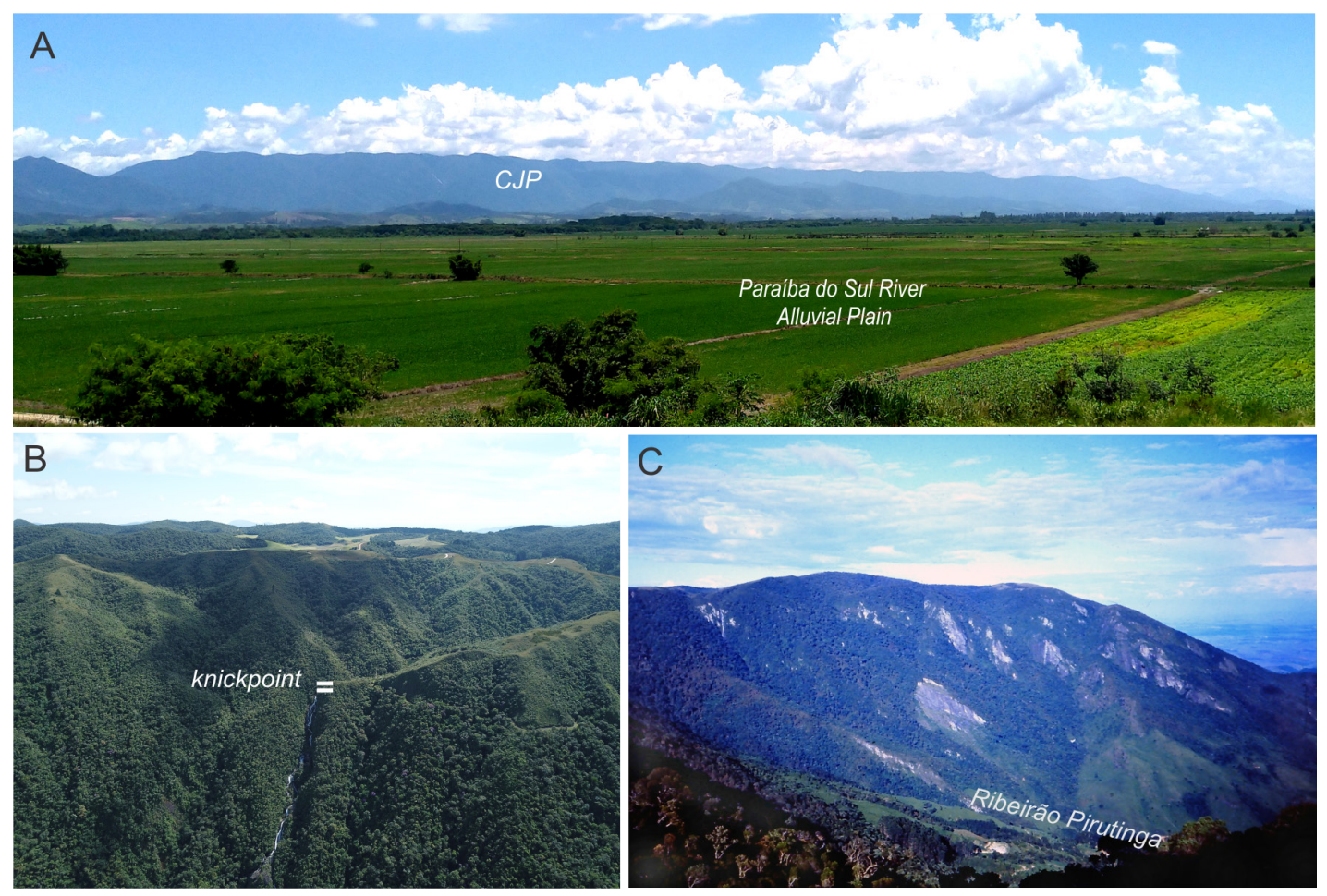

D

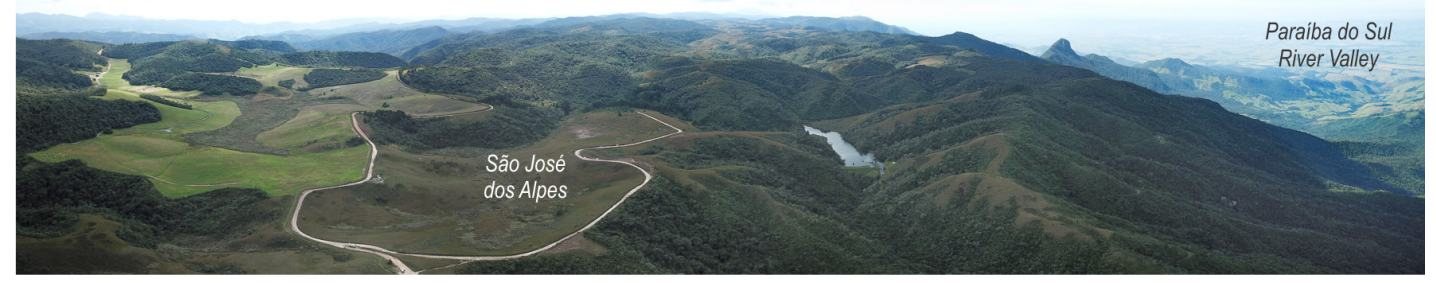

FIGURE 4: (A) The Serra da Mantiqueira at the southeastern border of the Campos do Jordão Plateau (CJP). Photo view from Quiririm (SP), Paraíba do Sul River Valley. (B) Scarp of the Serra da Mantiqueira - headwaters of the Ribeirão Grande, São José dos Alpes. Knickpoint along the NE-SW morphostructural lineament. (C) Scarp of the Serra da Mantiqueira - Ribeirão Pirutinga Valley. (D) Highest portion (1,900 - 2,007 m) of the studied area, near the scarp of the Serra da Mantiqueira (campos de São Francisco), characterized by low relief. Drone photos (B) and (D) by José A. Ferrari. See location of the photos in the map (Appendix 1).

deeply incised valleys of the scarp of the Serra da Mantiqueira (Figure 4B). Altitude decreases northwestwards reaching $1,300 \mathrm{~m}$ in Ribeirão dos Marmelos; the highest crests in this sector are associated with quartzites $(1,700 \mathrm{~m}$ - Morro da Pedra do Fogo).

NE-SW asymmetric valleys with southeasternfacing rectilinear scarps (Figure 5A, B) occur in general parallel to the subsequent drainage of the plateau. The height range of the scarps varies from $20 \mathrm{~m}$ to $70 \mathrm{~m}$ in the campos de São Francisco and up to $150-200 \mathrm{~m}$, in the more dissected valleys of the Serrano geosytem.
Rocky outcrops are common on the steepest slopes $\left(>30^{\circ}\right)$. NNW-SSE crests truncate the NE-SW scarps. NE-SW crests occur along the subsequent drainage of the plateau and in the Mantiqueira scarp (Figure 5C).

Stages of erosional development of the rectilinear scarps gave origin to the trapezoidal and triangular facets (Figure 5D, E). These features occur aligned along the ENEWSW morphostructural lineaments parallel to the Paiol, Fojo, Casquilho, Ganha-Bola, Serrote, Galvão and Lavrinha streams, and are commonly associated with normal faults 

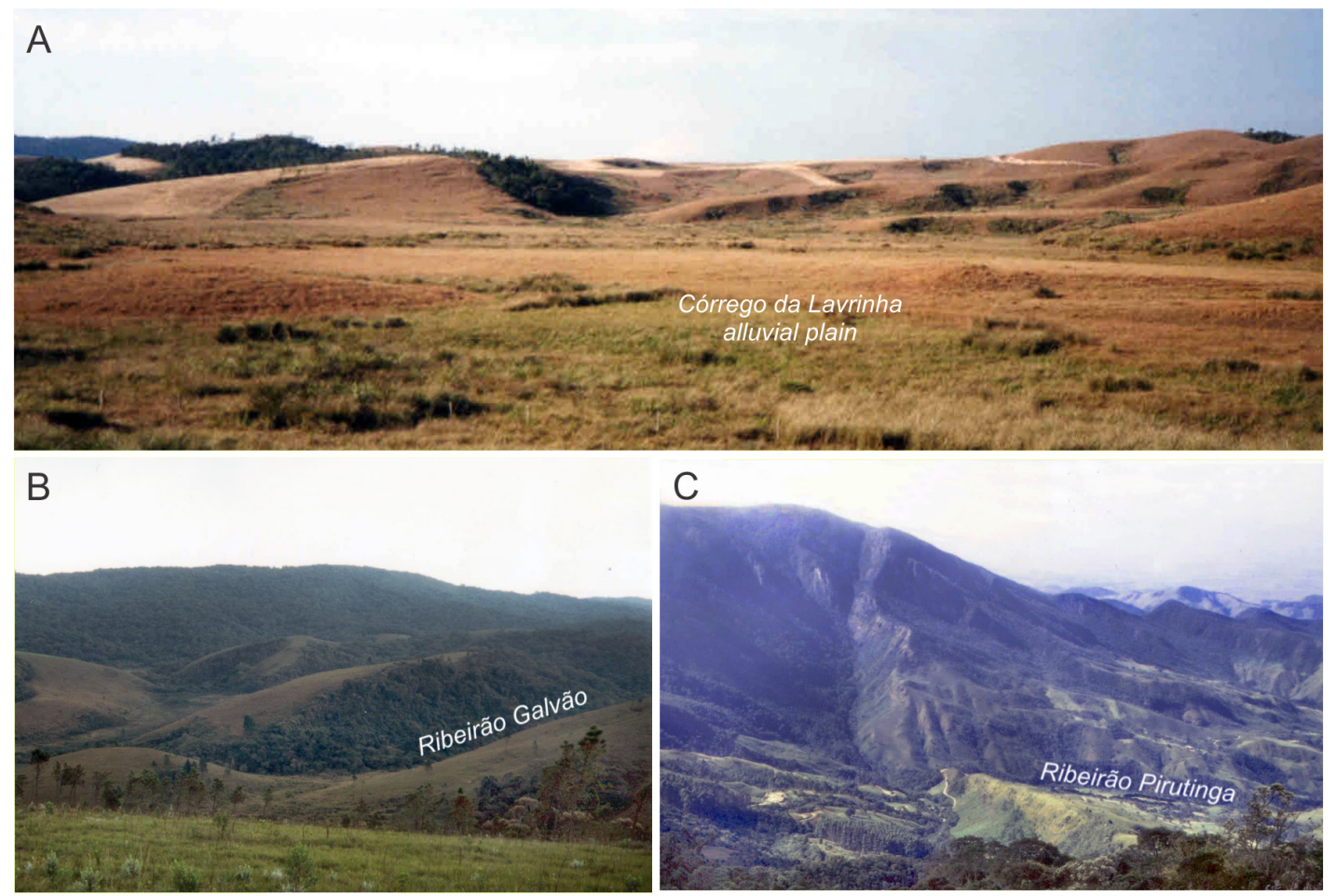

D

$\mathrm{E}$
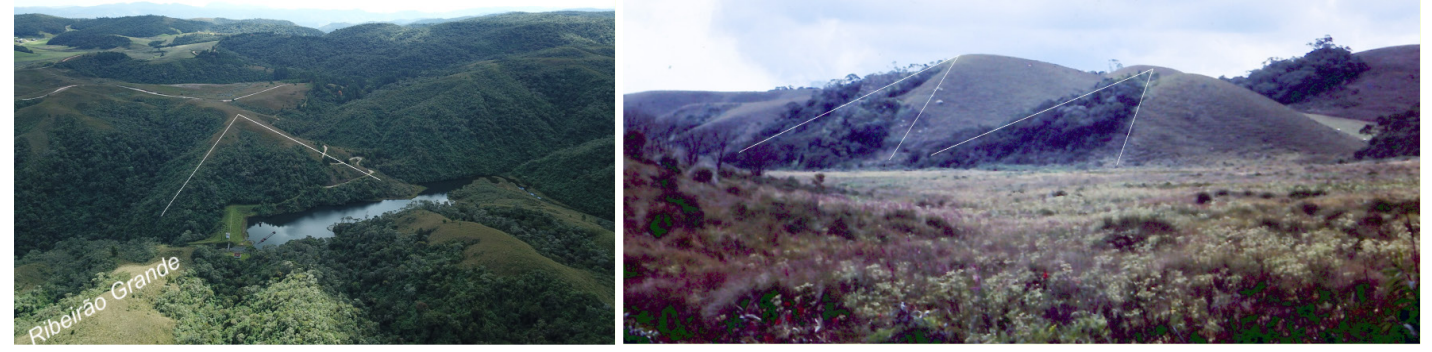

FIGURE 5 - (A) Tilted blocks with southeastern-facing scarps. (B) Southeastern-facing scarps covered with forest (Ribeirão Galvão). (C) Asymmetric crest at the foot of the Serra da Mantiqueira associated with ENE-WSW normal fault. Ribeirão Pirutinga cut its upthrow block epigenetically. (D) Triangular facet in the headwaters of the Ribeirão Grande. (E) NE-SW alignment of triangular facets associated with normal faults (Headwaters of the Ribeirão Pirutinga - Fazenda Lavrinha). See location of the photos in the map (Appendix 1). Drone photo (D) by José A. Ferrari.

or strike-slip ones with normal component. In some cases, triangular and trapezoidal facets occur on both sides of the valley (e.g. Córrego da Lavrinha and Ribeirão Galvão), which could be explained by the opposite fault dips associated with negative flower structures, or subvertical closely spaced faults.

The erosion amphitheaters in the Campos do Jordão Plateau (Figure 6A-D) were generated by different phases of mobilization of deep weathered regoliths, probably related to slump-slides, during the Pleistocene (MODENESI 1988b). They occur hanging over the current thalwegs. Amphitheaters associated with trapezoidal and triangular facets occur widespread along the NESW morphostructural lineaments in the altos campos area.

Shutter ridges, low drainage divides and knickpoints occur at the intersection between NESW and NNW-SSE morphostructural lineaments. 

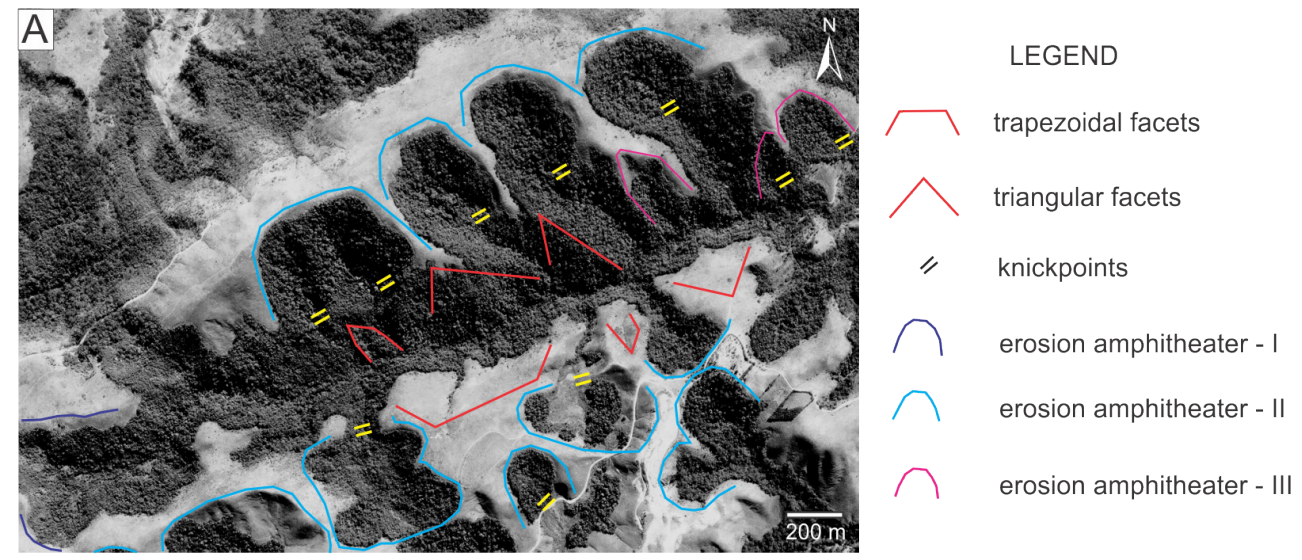

B
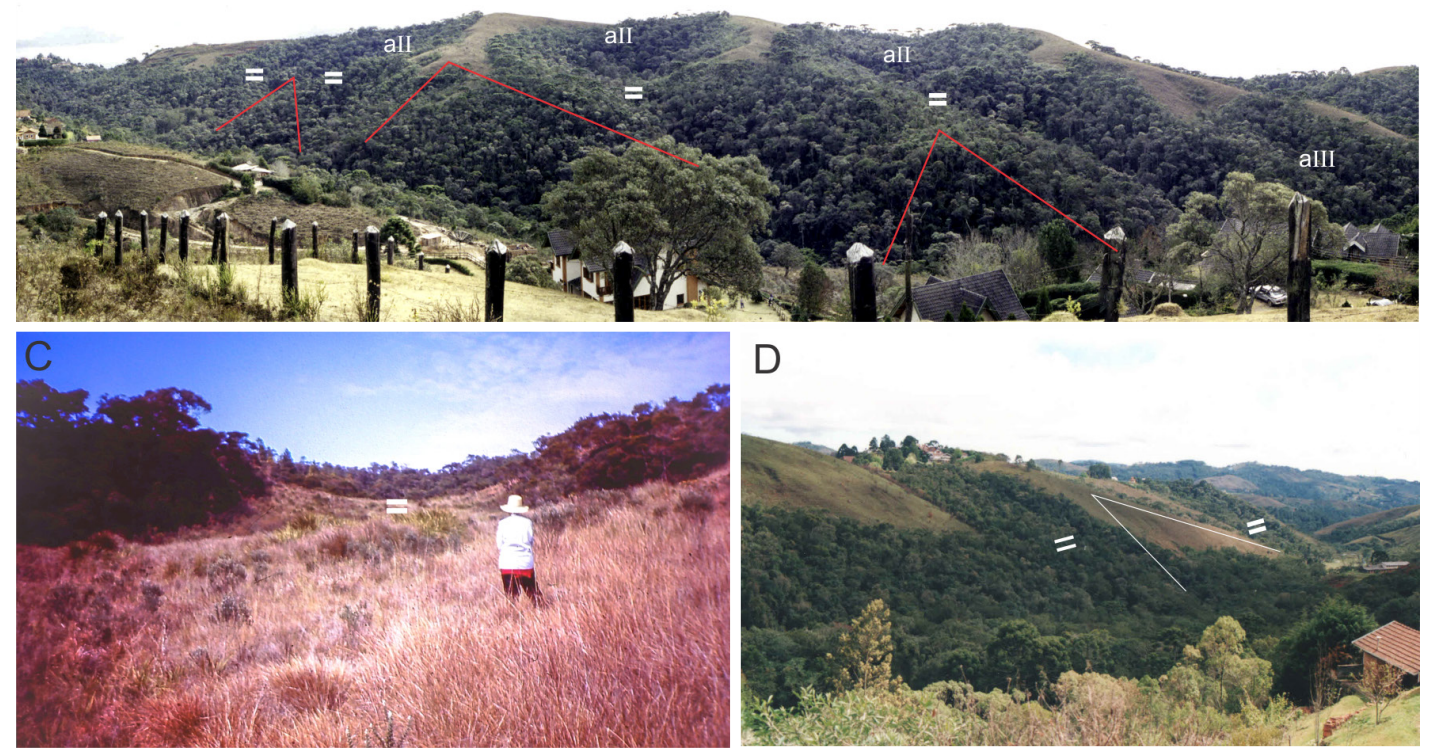

FIGURE 6 - (A) Erosion amphitheaters and triangular and trapezoidal facets in Morro da Pedra do Fogo (Modified from MODENESI 1988b). Vertical aerial photograph - scale 1:25.000. (B) Two generations of erosion amphitheaters (aII, aIII) and triangular facets in Morro da Pedra do Fogo. (C) Hanging amphitheater (see knickpoint). (D) Erosion amphitheaters along the Córrego das Pedras. See location of the photos in the map (Appendix 1).

In the campos de São Francisco, shutter ridges subdivide the Ribeirão Galvão Valley into three sectors with different geomorphic characteristics (see MODENESI-GAUTTIERI et al. 2002 for more detailed information) (Figure 7). The first valley sector is U-shaped, with prominent southeast-facing scarps $(70 \mathrm{~m}$ in height $)$, a 250 m-wide floodplain, poorly developed amphitheaters in the northern-facing convex slopes, and rocky outcrops on both hillslopes. The second valley sector (G2) is characterized by asymmetric valleys with southeast-facing scarps
(30-50 $\mathrm{m}$ in height) and northern-facing slopes with two generations of amphitheaters and triangular facets. The third valley sector (G3) is characterized by a broad alluvial plain (up to 150 -m wide) with meanders and lakes. Triangular facets occur in the southeast-facing slopes, and amphitheater generations on the north-facing slopes.

MODENESI-GAUTTIERI et al. (2002) identified several occurrences of the piracy phenomena along the Jundiuvira Shear Zone in the area of campos de São Francisco. Low divides associated with the NNW-strike-slip 

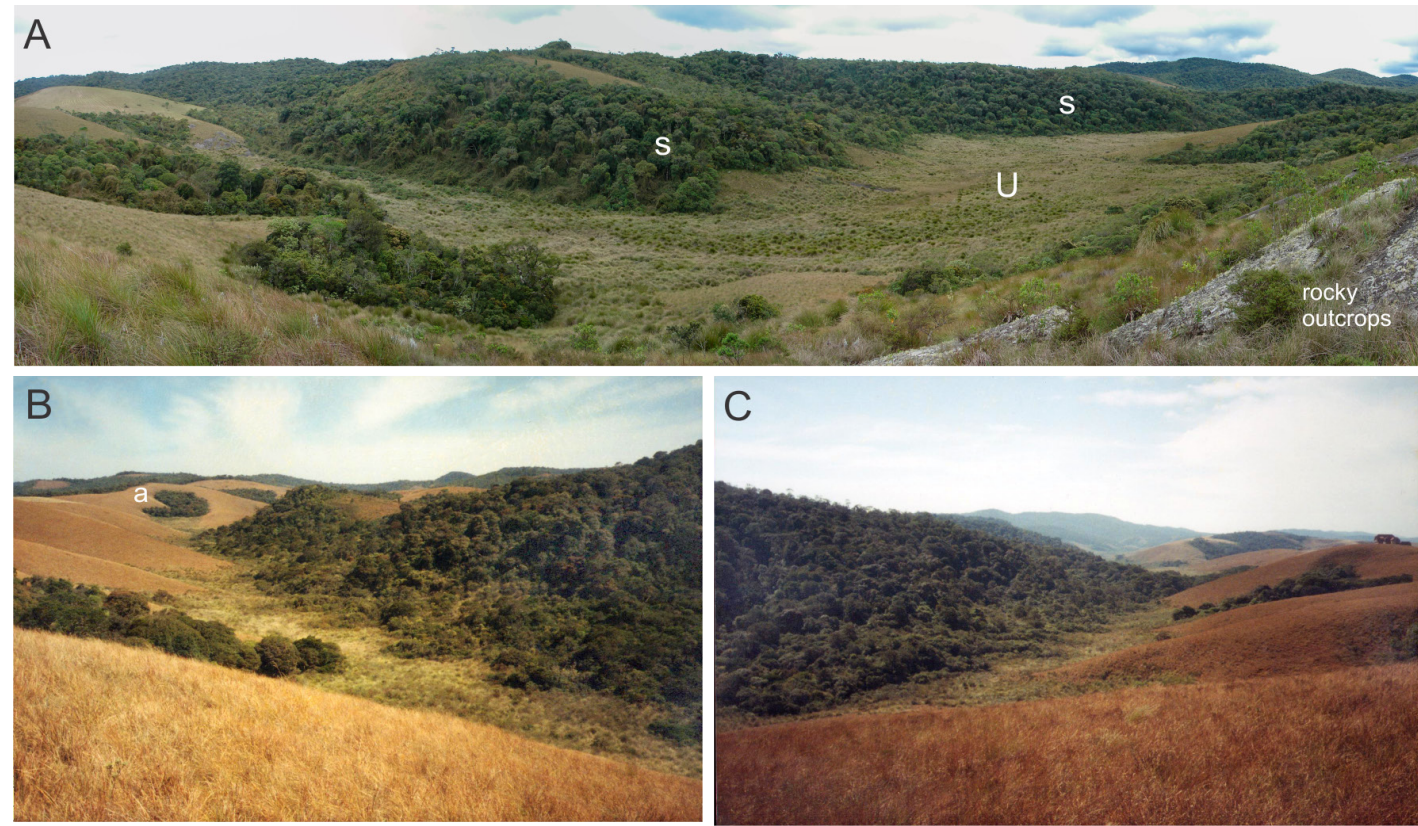

C

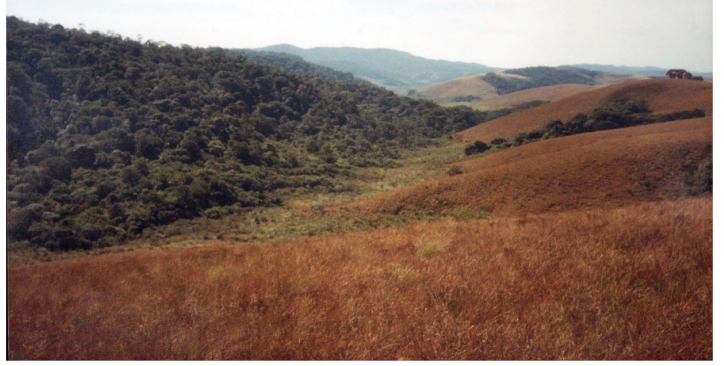

D

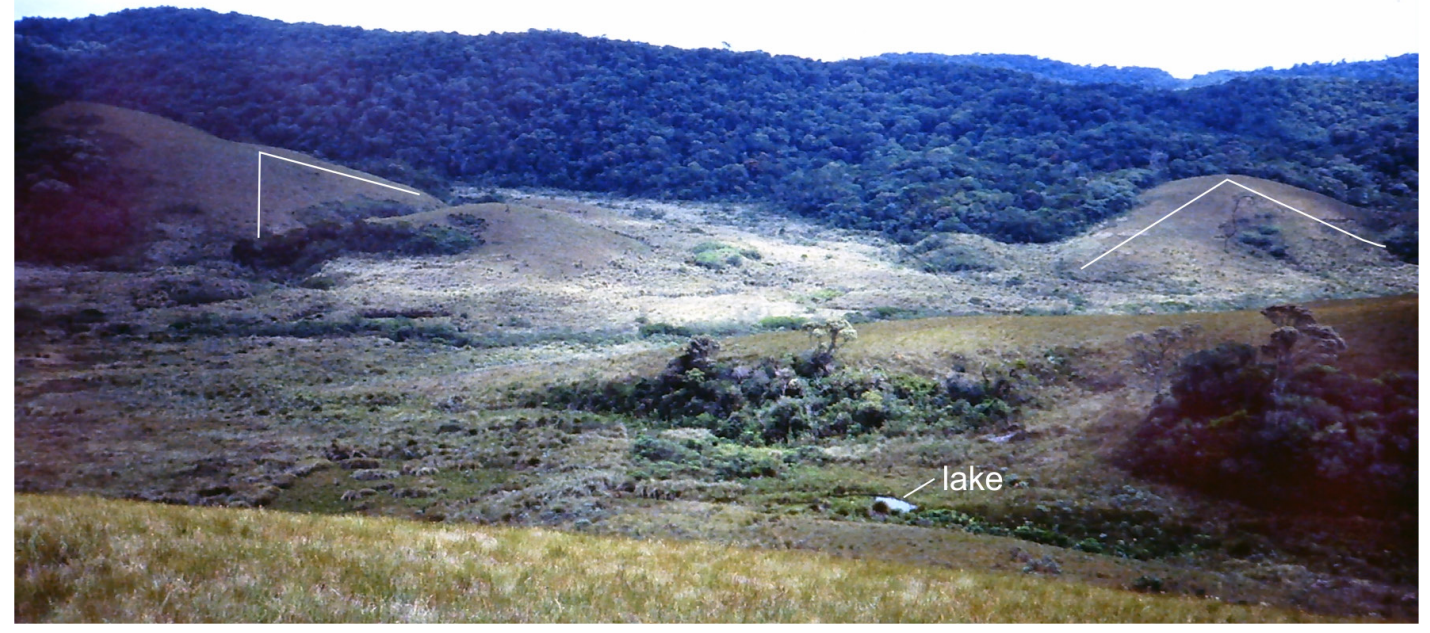

FIGURE 7 - Valley sectors of the Ribeirão Galvão. (A) The U-shaped (U) first valley sector (G1) with southeast-facing scarps (s). The rhombohedral shape of the valley, bounded by NW-SE and NE-SW faults, is characteristic of pull-apart basins. (B) and (C) Asymmetric valleys with southeast-facing scarps (s) and northern-facing slopes with hanging amphitheaters (a) in the second valley sector (G2). (D) Broad alluvial plain with meanders and lakes in the third valley sector (G3). Remnants of triangular facets occur in the southeast-facing slopes. See location of the photos in the map (G1, G2, G3 - Appendix 1).

faults separates the headwaters of Ribeirão Grande and Ribeirão do Sino (Figure 8A, B) basins, conditioning their capture by the streams of the Serra da Mantiqueira scarp. A complex zone of capture involves the headwaters of the Galvão, Pirutinga and Lavrinha streams (Figure 8C, Appendix 1).

Evidence of the piracy phenomena is also observed along the Galhada, Campo do Meio and
Ganha-Bola streams (Figure 8D) in the campos do Jordão area.

The offset crests and rivers, shutter ridges and low divides observed in the Campos do Jordão Plateau are in general associated with ENE-WSW/ WNW-ESE and NNW-SSE subvertical strike-slip faults. These faults are related to an E-W rightlateral transcurrent binary (Late Pleistocene/ 

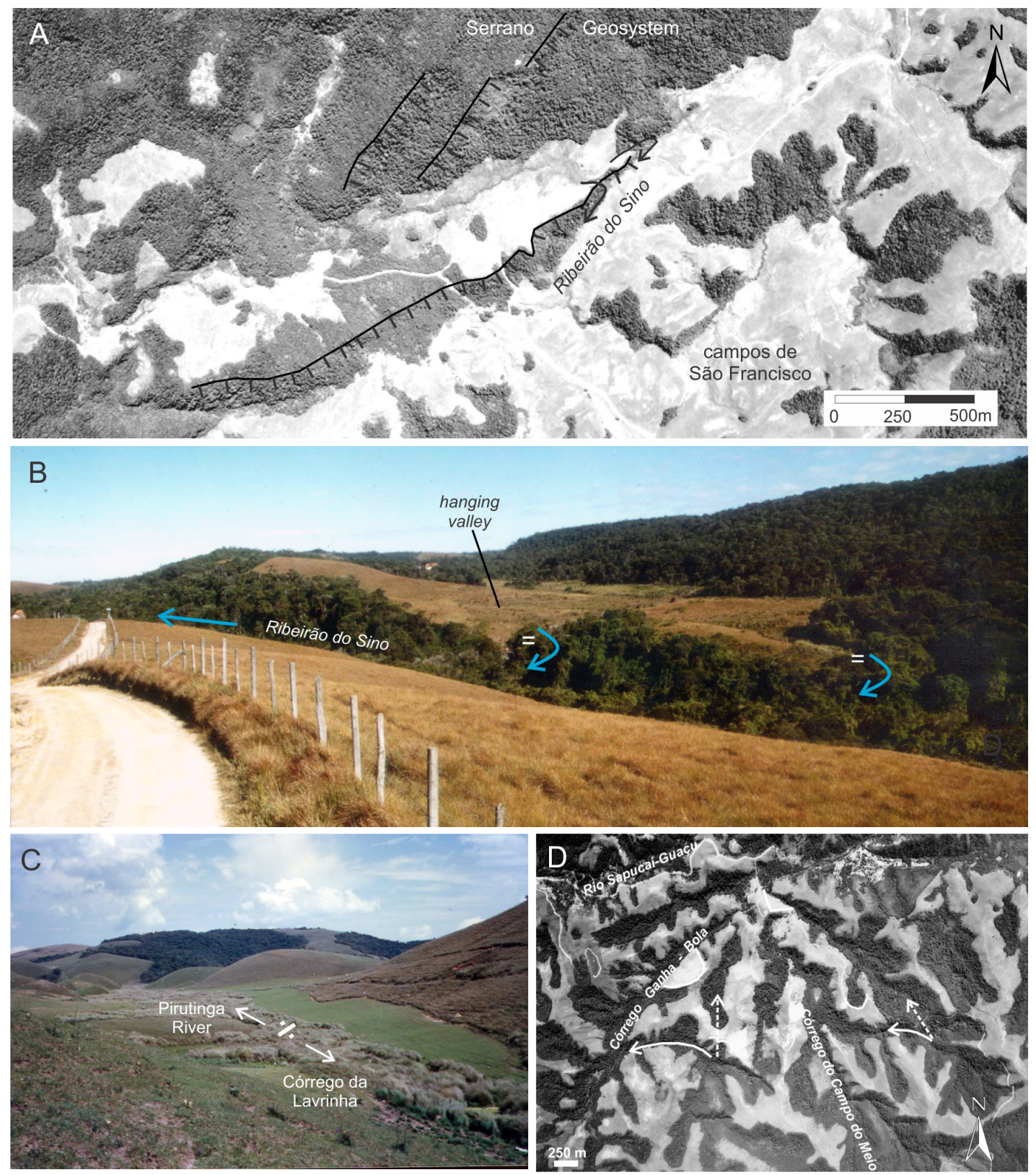

Figura 8: (A) Hanging valley and elbow of capture associated with NE-SW and NNW-SSE faults. Vertical aerial photograph - scale 1:25.000. (B) Local view of the river captures shown in (A). (C) Low divide separating the Lavrinha from the Pirutinga basins. See location of the photos in the map (Appendix 1). (D) Probable river captures along Córrego Ganha-Bola and Córrego do Campo do Meio.

Holocene NW-SE compression) (Figure 9), also identified in the central segment of the Continental Rift of Southeastern Brazil (RICCOMINI 1989, RICOOMINI et al. 2004), where they offset Paleogene deposits and Quaternary stone-lines.

Rectilinear scarps, hanging valleys and amphitheaters, and triangular and trapezoidal facets are in general associated with NE-SW/ENE-WSW high-angle to subvertical normal faults (Figure 10) with centimetric to decimetric offsets, parallel to the Jundiuvira Shear Zone, which cut stone-lines and A-humic horizons. These faults are related to an E-W/NW-SE extension (Holocene).

The Jundiuvira Shear Zone was tectonically reactivated under NW-SE compression as right- 


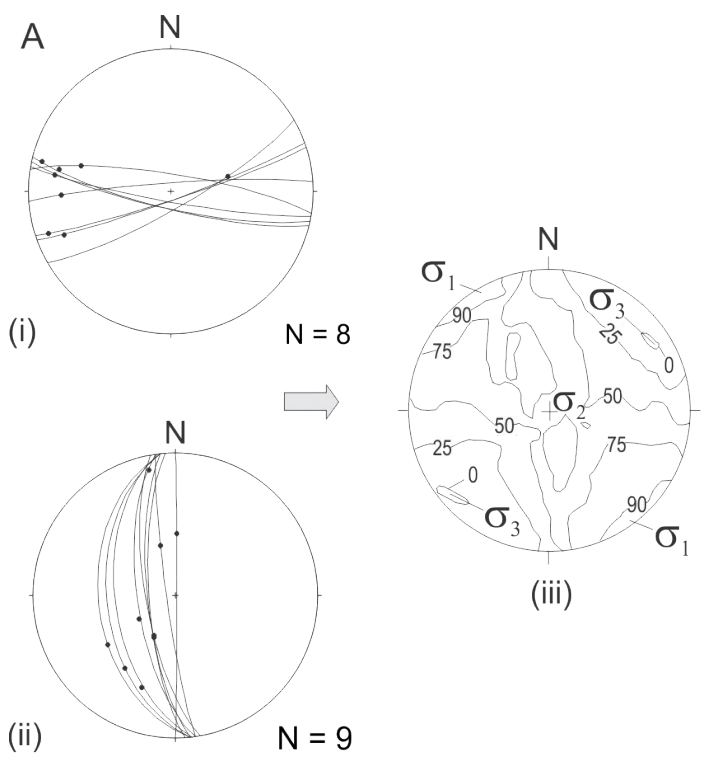

Equal area projection, lower hemisphere

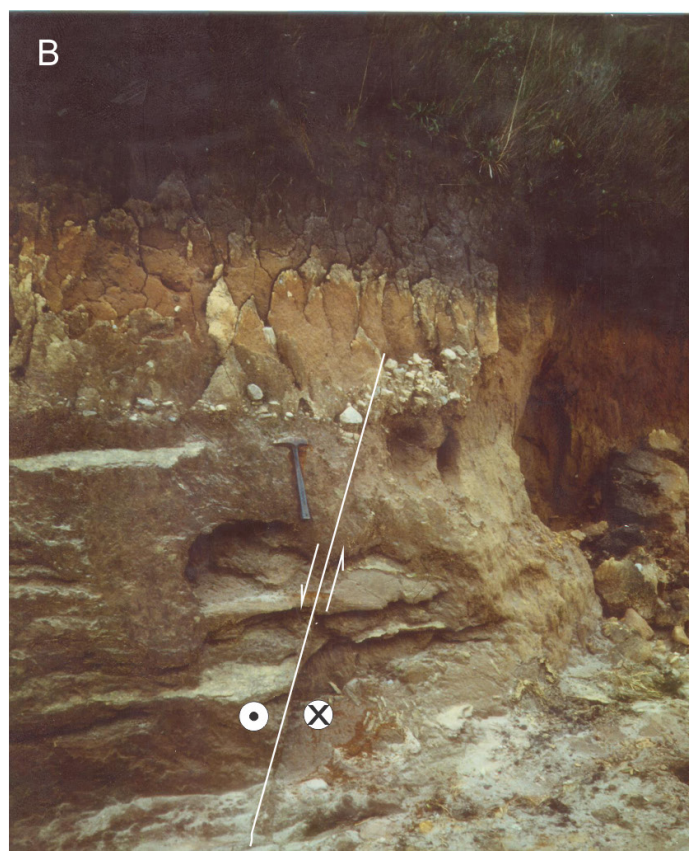

FIGURA 9 - (A) Faults associated with the NW-SE compressional phase (Upper Pleistocene/Holocene): (i) ENE-WSW/WNW-ESE right-lateral strike-slip faults (great circles) and striae (dots); (ii) NNW-SSE left-lateral strike-slip faults (great circles) and striae (dots); (iii) Determination of maximum and minimum principal stress directions using the graphic method of ANGELIER \& MECHLER (1977), where the higher and lower isoline values (in \%) indicate, respectively, the higher and lower probability fields for the maximum $(\sigma 1)$ and minimum $(\sigma 3)$ stress axes. (B) NNW Strike-slip fault with normal component affecting stone-line. See location of the photo in the map (Appendix 1). Modified from HIRUMA et al. (2001) and MODENESI-GAUTTIERI et al. (2002).
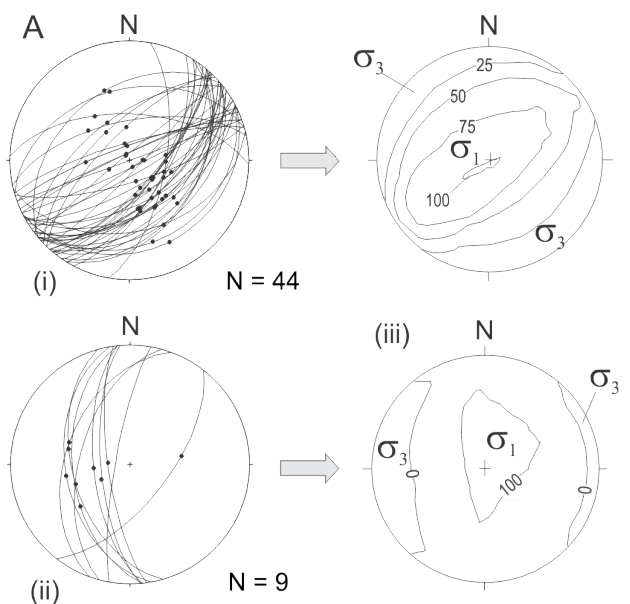

Equal area projection, lower hemisphere

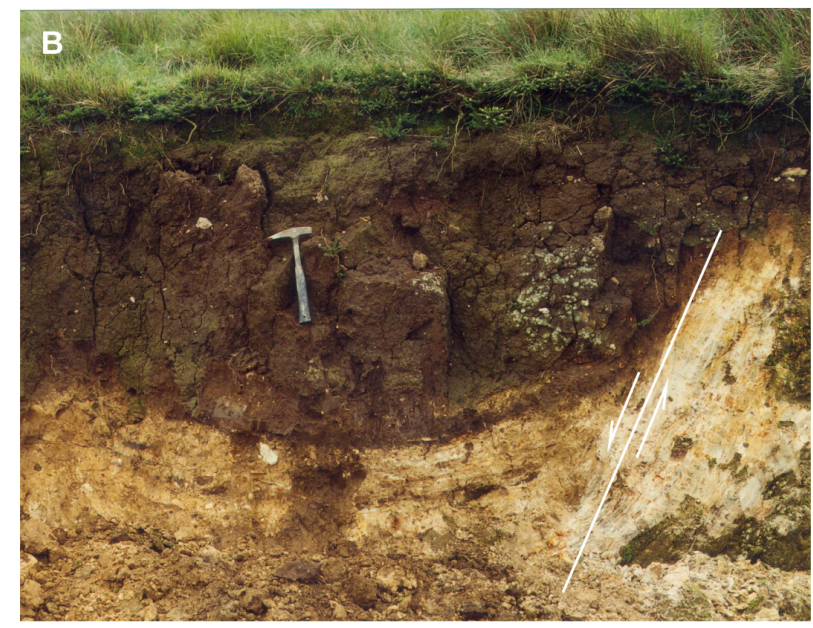

FIGURE 10 - (A) Faults associated with the NW-SE/E-W extensional phase (Holocene): (i) NE-SW normal faults (great circles) and striae (dots); (ii) N-S normal faults (great circles) and striae (dots); (iii) Determination of maximum and minimum principal stress directions using the graphic method of ANGELIER \& MECHLER (1977), where the higher and lower isoline values (in \%) indicate, respectively, the higher and lower probability fields for the maximum $(\sigma 1)$ and minimum ( $\sigma 3)$ stress axes. Modified from HIRUMA et al. (2001). (B) NE-SW normal fault affecting Quaternary deposit. See location of the photo in the map (Appendix 1). 
lateral strike-slip fault, and as a normal fault during NW-SE extension.

In the Campos do Jordão Plateau, river captures occur associated with normal and strike-slip Quaternary faults. Piracy phenomena associated with the deformation phases of the rift has been reported along the Paraíba do Sul River Valley, of which the most prominent example is the Neogene capture of the headwaters of the Paraíba do Sul River by the Tietê River (Figure 1) (AB'SÁBER 1957, RICCOMINI et al. 2010).

Brittle faults identified in the plateau are coherent with the tectonic stress regimes recognized along the continental rift (RICCOMINI 1989, RICCOMINI et al. 2004, FERRARI 2001, SILVA \& MELLO 2011) and in other areas of Southeastern Brazil (FERNANDES DA SILVA 1998, MELLO et al. 1999, FERNANDES \& AMARAL 2002, HARTWIG \& RICCOMINI 2009).

\section{CONCLUSIONS}

The Campos do Jordão Plateau, Serra da Mantiqueira, exposes several neotectonicrelated landforms. The morphotectonic map here presented at the scale 1:25,000 integrates geomorphological, lithological and structural data, using a morphotectonic approach. It is the result of topographic and morphometric analyses, detailed aerial photography and remote sensing imagery interpretation, supported by field surveys.

The preservation of the morphotectonic features in a tropical climate is indicative of recent tectonic activity. Hanging amphitheaters, triangular and trapezoidal facets, knickpoints and rectilinear scarps are generally associated with normal faults, whereas shutter ridges and low divides are associated with strike-slip faults. River captures occur associated with both types of faults. Tectonic stress regimes are similar to those observed in other areas of Southeastern Brazil.

Uplift processes and brittle tectonics had a pronounced influence on the evolution of the relief and drainage net of the Campos do Jordão Plateau, highlighting the importance of neotectonics in Southeast Brazil.

The mapping of morphotectonic features provides new insight for the recognition of neotectonic processes in intraplate settings, such as those found within Brazilian territory.

\section{ACKNOWLEDGMENTS}

This research was supported by FAPESP Fundação de Amparo à Pesquisa do Estado de São Paulo (96/08239-5, 03/08031-0, 2014/016487). CR thanks CNPq - Conselho Nacional do Desenvolvimento Científico e Tecnológico, for the research grant $\# 312510 / 2017-9$. The authors also thank the referees for providing helpful comments

\section{REFERENCES}

AB'SÁBER, A.N. 1957. O problema das conexões antigas e da separação da drenagem do Paraíba e do Tietê. Boletim Paulista de Geografia, 26:38-49.

AB'SÁBER, A.N. 2000. Summit surfaces in Brazil. Revista Brasileira de Geociências, 30(3): 515-516. http://dx.doi.org/10.25249/03757536.2000303515516

ALMEIDA， F.F.M. 1964. Fundamentos geológicos do relevo paulista. Boletim do Instituto Geográfico e Geológico, 41:169263. Republicado em Revista do Instituto Geológico, 39(3): 9-75, 2018. https://doi. org/10.33958/revig.v39i3.600

ALMEIDA, F.F.M.; HASUI, Y. 1984. Introdução. In: F.M.M. Almeida, Y. Hasui (eds.) O Précambriano do Brasil. São Paulo, Edgard Blücher, p. 1-5.

ANGELIER, J. 1994. Fault slip analysis and palaeostress reconstruction. In: P.L. Hancock (ed.) Continental Deformation. $1^{\text {st }}$ ed., Oxford, Pergamon Press, p. 53-100.

ANGELIER, J.; MECHLER, P. 1977. Sur une méthode graphique de recherche des constraintes principales également utilisable en tectonique et en séismologie: la méthode des dièdres droits. Bulletin de la Société Géologique de France, 7: 1309-1318. http://dx.doi.org/10.2113/gssgfbull.S7XIX.6.1309

BIANCOTTI, A. 1979. Rapporti fra morfologia e tettonica nella pianura cuneese. Geografia Fisicia e Dinamica Quaternaria, 2: 51-56.

BRITO NEVES, B.B.; CAMPOS NETO, M.C.; FUCK, R.A. 1999. From Rodinia to Western 
Gondwana: an approach to the BrasilianoPan African Cycle and orogenic collage. Episodes, 22(3): 155-166. https://doi. org/10.18814/epiiugs/1999/v22i3/002

CAMPANHA, G.A.C.; ENS, H.H.; PONÇANO, W.L. 1994. Análise morfotectônica do Planalto do Juqueriquerê, São Sebastião. Revista Brasileira de Geociências, 24(1): 32-42. http://dx.doi.org/10.25249/03757536.19943242

CAMPOS NETO, M.C. 2000. Orogenic systems from southwestern Gondwana. An approach to Brasiliano-Pan African Cycle and orogenic collage in southeastern Brazil. In: U.G. Cordani et al. (eds.) Tectonic evolution of South America. Rio de Janeiro, 31st International Geological Congress, p. 335365 .

CAVALCANTE, J.C.; CUNHA, H.C.S.; CHIEREGATI, L.A.; KAEFER, L.Q.; ROCHA, J.M.; DAITX, E.C.; COUTINHO, M.G.N.; YAMAMOTO, K.; DRUMOND, J.B.V.; ROSA, D.B.; RAMALHO, R. 1979. Projeto Sapucai - Estados de Minas Gerais e São Paulo. Relatório Final de Geologia. Brasília, DNPM/CPRM, Brasília, 299 p. (Série Geologia 5, Seção Geologia Básica 2).

COGNÉ, N.; GALLAGHER, K.; COBBOLD, P.R.; RICCOMINI, C.; GAUTHERON, C. 2012. Post-breakup tectonics in southeast Brazil from thermochronological data and combined inverse forward thermal history modeling. Journal of Geophysics Research, 117: B11413. https://doi. org/10.1029/2012JB009340

COTTON, C.A. 1948. Landscape - as developed by the processes of normal erosion. John Wiley \& Sons, New York, $2^{\text {nd }}$ ed., 509 p.

CPRM - SERVIÇO GEOLÓGICO DO BRASIL. 2006. Mapa da Geodiversidade do Brasil, escala 1: 2.500.000. Brasília, CPRM, Secretaria de Geologia, Mineração e Transformação Mineral, Ministério de Minas e Energia. https://rigeo.cprm.gov.br/ handle/doc/10169
DE MARTONNE, E. 1943. Problemas morfológicos do Brasil tropical Atlântico. Revista Brasileira de Geografia, 4: 523-550.

DOBLAS M.; MAHECHA V.; HOYOS M.; LÓPEZ-RUIZ J. 1997. Slickenside and fault surface kinematic indicators on active normal faults of the Alpine Betic cordilleras, Granada, southern Spain. Journal of Structural Geology, 19(2): 159-170. https:// doi.org/10.1016/S0191-8141(96)00086-7

DOORNKAMP, J.C. 1986. Geomorphological approaches to the study of neotectonics. Journal of the Geological Society, 143: 335-342. https://doi.org/10.1144/ gsjgs.143.2.0335

FERNANDES, A.J.; AMARAL， G. 2002. Cenozoic tectonic events at the border of the Paraná Basin, São Paulo, Brazil. Journal of South American Earth Sciences, 14: 911-931. https://doi.org/10.1016/S08959811(01)00078-5

FERNANDES DA SILVA, P.C. 1998. Tectônica rúptil da região entre Votorantim $\mathrm{e}$ Pilar do Sul, SP. Revista Brasileira de Geociências, 28(4): 485-494. http://dx.doi. org/10.25249/0375-7536.1998485494

FERRARI, A.L. 2001. Evolução tectônica do Graben da Guanabara. Instituto de Geociências, Universidade de São Paulo, São Paulo, Tese de Doutorado, 412 p.

GALLAGHER, K.; HAWKESWORTH， C.J.; MANTOVANI, M.S.M. 1994. The denudation history of the onshore continental margin of SE Brazil inferred from apatite fission track data. Journal of Geophysical Research Solid Earth, 99(B9): 18117-18145. https:// doi.org/10.1029/94JB00661

GONTIJO, A.H.F. 1999. Morfotectônica do Médio Vale do Rio Paraíba do Sul: região da Serra da Bocaina, leste do Estado de São Paulo. Instituto de Geociências e Ciências Exatas, Universidade Estadual Paulista, Rio Claro, Tese de Doutorado, 265 p.

GONTIJO-PASCUTTI, A.; BEZERRA, F.H.R.; LA TERRA, E.; ALMEIDA, J.C.H. 2010. Brittle reactivation of mylonitic fabric and the origin of the Cenozoic Rio 
Santana Graben, southeastern Brazil. Journal of South American Earth Sciences, 29(2): 522-536. https://doi.org/10.1016/j. jsames.2009.06.007

GOY, J.L.; SILVA, P.G.; ZAZO, C.; BARDAJI, T.; SOMOZA, L. 1991. Model of morphoneotectonic map and legend. Bulletin Inqua N.C., 14: 19-31.

GROHMANN, C.H.; RICCOMINI, C.; ALVES, F.M. 2007. SRTM-based morphotectonic analysis of the Poços de Caldas Alkaline Massif, southeastern Brazil. Computers \& Geosciences, 33(1): 10-19. https://doi. org/10.1016/j.cageo.2006.05.002

GUEDES, I.C.; ETCHEBEHERE, M.L.C.; MORALES,N.;STEVAUX,J.C.;SANTONI, G.C. 2009. Análise morfotectônica da bacia do rio Santo Anastácio, SP, através de parâmetros fluviomorfométricos e de registros paleossísmicos. Geociências, 28(4): 247-362.

HACKSPACHER， P.C.; RIBEIRO， L.F.B.; RIBEIRO, M.C.S.; FETTER, A.H.; HADLER NETO, J.C.; TELLO SAENZ, C.A.; DANTAS, E.L. 2004. Consolidation and break-up of the South American platform in SE Brazil: tectonothermal and denudation histories. Gondwana Research, 7: 91-101. https://doi.org/10.1016/S1342937X(05)70308-7

HARTWIG, M.E.; RICCOMINI, C. 2009. Padrão de fraturas da região da Serra dos Órgãos (RJ) e sua relação com a tectônica mesozóico-cenozóica do sudeste do Brasil. Revista Brasileira de Geociências, 39(3): 452-464. http://dx.doi.org/10.25249/03757536.2009394452464

HARTWIG, M.E.; RICCOMINI, C. 2010. Análise morfotectônica da região da Serra dos Órgãos, sudeste do Brasil. Revista Brasileira de Geomorfologia, 11(1): 11-20. http://dx.doi.org/10.20502/rbg.v11i1.137

HASUI, Y.; PONÇANO, W.L; BISTRICHI, C.A.; STEIN,D.P.;GALVÃO,C.A.C.F.; GIMENEZ, A.F.; ALMEIDA, M.A.; PIRES NETO, A.G.; MELO, M.S.; SANTOS, M.C.S.R. 1978. Geologia da Região Administrativa 3 (Vale do Paraíba) e parte da Região Administrativa
2 (Litoral) do Estado de São Paulo. Instituto de Pesquisas Tecnológicas, São Paulo, 78 p. (Publicação 1106).

HIRUMA, S.T. 1999. Neotectônica no Planalto de Campos do Jordão, SP. Instituto de Geociências, Universidade de São Paulo, São Paulo, Dissertação de Mestrado, 106 p. http://dx.doi.org/10.11606/D.44.1999.tde15052014-094033

HIRUMA, S.T.; RICCOMINI, C.; MODENESIGAUTTIERI, M.C. 2001. Neotectônica no Planalto de Campos do Jordão, SP. Revista Brasileira de Geociências, 31(3): 375-384. http://dx.doi.org/10.25249/03757536.2001313375384

HIRUMA, S.T.; RICCOMINI, C; MODENESIGAUTTIERI, M.C.; HACKSPACHER, P.C.; HADLER NETO, J.C.; FRANCOMAGALHÃES, A.O.B. 2010. Denudation history of the Bocaina Plateau, Serra do Mar, southeastern Brazil: relationships to Gondwana breakup and passive margin development. Gondwana Research, 18: 674687. https://doi.org/10.1016/j.gr.2010.03.001

HURFORD, A.J. 1990. International Union of Geological Sciences Subcommission on Geochronology recommendation for the standardization of fission track dating calibration and data reporting. International Journal of Radiation Applications and Instrumentation. Part D. Nuclear Tracks and Radiation Measurements, 17: 233 -236. https:// doi.org/10.1016/1359-0189(90)90040-5

LIU, C.C. 1987. A geologia estrutural do Estado do Rio de Janeiro vista através de imagens MSS do Landsat. In: SBG, SIMPÓSIO DE GEOLOGIA REGIONAL RJ-ES, 1, Rio de Janeiro, Anais, 164 -188.

MARQUES NETO, R.; PEREZ FILHO, A. 2013. Análise morfoestrutural e morfotectônica da Bacia do Rio Capivari, sul de Minas Gerais: A Neotectônica e as superfícies geomorfológicas. Revista Brasileira de Geomorfologia, 14(4): 271-277. http:// dx.doi.org/10.20502/rbg.v14i4.178

MELLO, C.L.; METELO, C.M.S.; SUGUIO, K.; KOHLER, H.C. 1999. Quaternary sedimentation, neotectonics and the 
evolution of the Doce River Middle Valley Lake System (Southern Brazil). Revista do Instituto Geológico, 20(1/2): 29-36. http:// dx.doi.org/10.5935/0100-929X.19990003

MELO, M.S; RICCOMINI, C.; HASUI, Y.; ALMEIDA, F.F.M.; COIMBRA, A.M. 1985. Geologia e evolução do sistema de bacias tafrogênicas continentais do sudeste do Brasil. Revista Brasileira de Geociências, 15(3): 193-201. http://dx.doi. org/10.25249/0375-7536.1985193201

MELO, M.S.; STEIN, D.P.; PONÇANO, W.L.; BISTRICHI, C.A. 1993. Neotectônica da área do Alto Rio Pardo (SP e MG). Revista do Instituto Geológico, 14(2): 27-38. http:// dx.doi.org/10.5935/0100-929X.19930008

MENDES, L.D.; FERNANDES, N.F.; GONTIJOPASCUTTI, A. 2007. Morfotectônica da bacia hidrográfica do rio Bonito, Petrópolis, RJ. Revista Brasileira de Geomorfologia, 8(1): 63-77. http://dx.doi.org/10.20502/rbg.v8i1.86

MODENESI, M.C. 1980. Intemperismo e morfogênese no Planalto de Campos do Jordão, São Paulo. Revista Brasileira de Geociências, 10(3):213-225. http://doi. org/10.25249/0375-7536.1980213225

MODENESI, M.C. 1983. Weathering and morphogenesis in a tropical plateau. Catena, 10(3): 237-251. https://doi. org/10.1016/S0341-8162(83)80020-4

MODENESI, M.C. 1988a. Significado dos depósitos correlativos quaternários em Campos do Jordão - São Paulo: implicações paleoclimáticas e paleoecológicas. São Paulo, Instituto Geológico, 155 p. (Boletim, 7).

MODENESI, M.C. 1988b. Quaternary mass movements in a tropical plateau (Campos do Jordão, São Paulo, Brazil). Zeitschrift für Geomorphologie, 32(4):425-440. https:// doi.org/10.1127/zfg/32/1988/425

MODENESI-GAUTTIERI, M.C.; HIRUMA S.T.; RICCOMINI, C. 2002. Morphotectonics of a high plateau on the northwestern flank of the Continental Rift of Southeastern Brazil. Geomorphology, 43: 257-271. https://doi. org/10.1016/S0169-555X(01)00137-4
MODENESI-GAUTTIERI, M.C.; TOLEDO, M.C.M.; HIRUMA S.T.; TAIOLI, F.; SHIMADA, H. 2011. Deep weathering and landscape evolution in a tropical plateau. Catena, 85(3): 221-230. https://doi. org/10.1016/j.catena.2011.01.006

MORAIS, S.M.; DEHLER, M.D.; RODRIGUES, J.B.; SACHS, L.L.B. 1999. Carta Geológica Guaratinguetá, SF.23-Y-B. Projeto Integração Geológico Metalogenética, Folha Rio de Janeiro. São Paulo, CPRM, carta geológica, escala 1:250.000.

MÖRNER, N. $1989 . \quad$ Introduction. Tectonophysics, 163(3/4): 181-184. https:// doi.org/10.1016/0040-1951(89)90255-2

NEVES, M.A.; MORALES, N.; BORGES, M.S.; EBERT, H.D. 2003. Compartimentação morfotectônica da região de Jundiaí (SP). Revista Brasileira de Geociências, 33(2): 167-176. http://dx.doi.org/10.25249/03757536.2003332167176

OBRUCHEV, V.A. 1948. Osnovnye cherty kinetiki i plastiki neotektoniki. Akademia Nauk SSSR, Izveztiya Seriya Geologiya, 5:13-24.

OLLIER, C.D. 1985. Morphotectonics of passive continental margins: introduction. Zeitschrift für Geomorphologie N.F., 54: 1-9.

PANIZZA, M.; CASTALDINI, D. 1987. Neotectonic research in applied geomorphological studies. Zeitschrift für Geomorphologie, 63 (Neotectonics and morphotectonics): 173 - 211.

PERROTA, M.M.; SALVADOR, E.D.; LOPES, R.C.; D'AGOSTINO, L.Z.; PERUFFO, N.; GOMES, S.D.; SACHS, L.L.B.; MEIRA, V.T.; LACERDA FILHO, J.V. 2005. Mapa Geológico do Estado de São Paulo - Programa Levantamentos Geológicos Básicos do Brasil. São Paulo, CPRM, escala 1:750.000.

PETIT, J.P. 1987. Criteria for the sense of movement on fault surfaces in brittle rocks. Journal of Structural Geology, 9(5/6): 597-608. https://doi.org/10.1016/01918141(87)90145-3

PINHEIRO, M.R.; QUEIROZ NETO, J.P. 2015. Neotectônica e evolução do relevo da 
região da Serra de São Pedro e do Baixo Rio Piracicaba. Revista Brasileira de Geomorfologia, 16(4): 593-613. http:// dx.doi.org/10.20502/rbg.v16i4.668

RICCOMINI, C. 1989. O Rift Continental do Sudeste do Brasil. Instituto de Geociências, Universidade de São Paulo, São Paulo, Tese de Doutoramento, 256 p. http://dx.doi. org/10.11606/T.44.1990.tde-18032013105507

RICCOMINI, C.; ASSUMPÇÃO, M. 1999. Quaternary tectonics in Brazil. Episodes, 22(3): 221-225. https://doi.org/10.18814/ epiiugs/1999/v22i3/010

RICCOMINI, C.; CRÓSTA, A.P. 1988. Análise preliminar de lineamentos em imagens de sensores remotos aplicada à prospecção mineral na área dos granitóides Mandira, $S P$. São Paulo, Instituto de GeociênciasUniversidade de São Paulo, p. 23-37 (Boletim 19, Série Científica).

RICCOMINI, C.; PELOGGIA, A.U.G.; SALONI, J.C.L.; KOHNKE, M.W.; FIGUEIRA, R.M. 1989. Neotectonic activity in the Serra do Mar rift system (southeastern Brazil). Journal of South American Earth Sciences, 2(2): 191-197. https://doi.org/10.1016/08959811(89)90046-1

RICCOMINI, C.; SANT'ANNA, L.G., FERRARI, A.L. 2004. Evolução geológica do Rift Continental do Sudeste do Brasil. In: V. Mantesso-Neto, A. Bartorelli, C.D.R. Carneiro, B.B. Brito Neves (eds) Geologia do Continente Sul-Americano: evolução da obra de Fernando Flávio Marques de Almeida. Beca, São Paulo, p. 393-405.

RICCOMINI, C.; GROHMANN, C.H.; SANT'ANNA, L.G.; HIRUMA, S.T. 2010. A captura das cabeceiras do Rio Tietê pelo Rio Paraíba do Sul. In: M.C. ModenesiGauttieri, A. Bartorelli, V. Mantesso-Neto, C.D.R. Carneiro, M.B.A. Lima. (Org.). A Obra de Aziz Nacib Ab'Sáber. Beca-Ball, São Paulo, p. 157-169.

RUELLAN, F. 1952. Excursão à região do Vale do Paraíba e à Serra da Mantiqueira. In: Reunião Panamericana Consulta sobre
Geogr., 1, Guia de excursão B. I., set./1949, Anais, 2: 206-251.

SAADI, A. 1991. Ensaio sobre a morfotectônica de Minas Gerais: tensões intra-placa, descontinuidades crustais e morfogênese. Instituto de Geociências, Universidade Federal de Minas Gerais, Belo Horizonte, Tese para cargo de Professor Titular, 285 p.

SILVA, T.P.; MELLO, C.L., 2011. Reativações Neotectônicas naZona de Cisalhamento do Rio Paraíba do Sul (Sudeste do Brasil). Geologia USP, Série Cientifica, 11: 95-111. https://doi. org/10.5327/Z1519-874X2011000100006

STEWART, I.S.; HANCOCK, P.L. 1990. What is a fault scarp? Episodes, 13(4): 256-263. https:// doi.org/10.18814/epiiugs/1990/v13i4/005

TEIXEIRA, A.L.; GAUCHER, C.; PAIM, P.S.G.; FONSECA, M.M.; PARENTE, C.V.; SILVA FILHO, W.F.; ALMEIDA, A.R. 2004. Bacias do estágio da transição da Plataforma Sul-Americana. In: V. Mantesso-Neto, A. Bartorelli, C.D.R. Carneiro, B.B. Brito Neves (eds) Geologia do Continente Sul-Americano: evolução da obra de Fernando Flávio Marques de Almeida. Beca, São Paulo, p. 487-536.

TELLO SAENZ, C.; HACKSPACHER, P.C.; HADLER NETO, J.C.; IUNES, P.J.; GUEDES, S.; RIBEIRO, L.F.B.; PAULO, S.R. 2003. Recognition of Cretaceous, Paleocene, and Neogene tectonic reactivation through apatite fission-track analysis in Precambrian areas of southeast Brazil: association with the opening of the South Atlantic Ocean. Journal of South American Earth Sciences, 15: 765-774. https://doi. org/10.1016/S0895-9811(02)00131-1

THOMAS, M.F. 1994. Geomorphology in the Tropics. Wiley, Chichester, $460 \mathrm{p}$.

VERSTAPPEN, H. Th. 1983. Applied Geomorphology - Geomorphological surveys for environmental development. Elsevier, Amsterdam, $437 \mathrm{p}$.

WALLACE, R.E. 1978. Geometry and rates of change of fault-generated range fronts, North-Central Nevada. Journal of Research of the U.S. Geological Survey, 6(5): 637-650. 
Authors' addresses:

Silvio Takashi Hiruma - Instituto de Pesquisas Ambientais, Secretaria de Infraestrutura e Meio Ambiente do Estado de São Paulo, Rua Joaquim Távora, 822, Vila Mariana, São Paulo, SP, CEP: 04015-011, Brazil. E-mail: shiruma@sp.gov.br

Claudio Riccomini - Instituto de Energia e Ambiente and Instituto de Geociências, Universidade de São Paulo, São Paulo, SP, CEP: 05508-010, Brazil.E-mail: riccomin@usp.br

May Christine Modenesi-Gauttieri - Rua Paiquerê, 530, ap. 62, Jardim Paiquerê, Valinhos, SP, CEP: 13271-600, Brazil.E-mail: maymodenesi@gmail.com

Manuscript submitted in 1 November 2021, accepted in 30 December 2021. 